\title{
Offshore wind farms and the attraction-production hypothesis: insights from a combination of stomach content and stable isotope analyses
}

\author{
Ninon Mavraki (iD) Steven Degraer · Jan Vanaverbeke
}

Received: 26 May 2020/Revised: 4 February 2021 / Accepted: 6 February 2021/Published online: 1 March 2021

(C) The Author(s) 2021

\begin{abstract}
Offshore wind farms (OWFs) act as artificial reefs, attracting high abundances of fish, which could potentially increase their local production. This study investigates the feeding ecology of fish species that abundantly occur at artificial habitats, such as OWFs, by examining the short- and the long-term dietary composition of five species: the benthopelagic Gadus morhua and Trisopterus luscus, the pelagic Scomber scombrus and Trachurus trachurus, and the benthic Myoxocephalus scorpioides. We conducted
\end{abstract}

Handling editor: Ivan Nagelkerken

Supplementary Information The online version contains supplementary material available at https://doi.org/10.1007/ s10750-021-04553-6.

N. Mavraki $(\bowtie) \cdot$ S. Degraer $\cdot$ J. Vanaverbeke Operational Directorate Natural Environment, Marine Ecology and Management, Royal Belgian Institute of Natural Sciences, Vautierstraat 29, 1000 Brussels, Belgium

e-mail: nmavraki@naturalsciences.be;

ninon.mavraki@wur.nl

N. Mavraki $\cdot$ S. Degraer · J. Vanaverbeke

Marine Biology Research Group, Department of Biology,

Ghent University, Krijgslaan 281/S8, 9000 Ghent,

Belgium

Present Address:

N. Mavraki

Wageningen Marine Research, Ankerpark 27,

1781AG Den Helder, The Netherlands combined stomach content and stable isotope analyses to examine the short- and the time-integrated dietary composition, respectively. Our results indicated that benthopelagic and benthic species utilize artificial reefs, such as OWFs, as feeding grounds for a prolonged period, since both analyses indicated that they exploit fouling organisms occurring exclusively on artificial hard substrates. Trachurus trachurus only occasionally uses artificial reefs as oases of highly abundant resources. Scomber scombrus does not feed on fouling fauna and therefore its augmented presence in OWFs is probably related to reasons other than the enhanced food availability. The long-termed feeding preferences of benthic and benthopelagic species contribute to the hypothesis that the artificial reefs of OWFs could potentially increase the fish production in the area. However, this was not supported for the pelagic species.

Keywords Artificial habitats · Feeding ecology · Fouling organisms . Offshore wind turbines

\section{Introduction}

Worldwide, the number of offshore renewable energy installations is increasing fast as a measure to mitigate the effects of climate change. In the southern part of the North Sea, offshore wind farms (OWFs) are being 
continuously constructed (Soma et al., 2019), adding artificial hard substrates (the foundations and the associated scour protection layers) to usually naturally soft bottom areas. These wind turbines act as artificial reefs, drastically altering the local habitat (Petersen \& Malm, 2006) and adding hard bottom communities to the original environment (Mangi, 2013). These communities consist of species exclusively occurring on artificial hard substrates and rarely observed on natural hard habitats (Zintzen, 2007). In the southern part of the North Sea, natural reefs are rare and are located on the Hinder Banks (gravel fields), the Cleaver Bank (gravel fields), the Texel Rough (boulder clay), and the Borkum Reef Grounds (rocky outcrops) (Veenstra, 1969; Dörjes, 1977; Coolen et al., 2015). Natural hard substrates (gravel beds) in the Belgian part of the North Sea are located at $\sim 15 \mathrm{~km}$ distance from the OWFs (Houziaux et al., 2008).

Artificial habitats usually accommodate higher densities of fish compared to natural reefs (Bohnsack $\&$ Sutherland, 1985), although the design and location of artificial reefs may influence these densities (Strelcheck et al., 2005). While OWFs act as fish aggregation devices (Wilhelmsson et al., 2006), the exploitation of the locally attracted fish is either not allowed within the OWF areas (e.g. Belgium) or it is partially allowed (e.g. Netherlands) or, finally, it is fully allowed but not largely exploited by fishers (e.g. UK). Two different hypotheses have been proposed to explain the increased fish abundances in artificial reefs (Brickhill et al., 2005). The attraction hypothesis proposes that fish move from the surrounding environment towards the artificial reefs, where their local production does not increase (Brickhill et al., 2005). The attraction to artificial reefs can be explained by the increased structural complexity resulting in an enhanced protection against predators, shelter from currents (Bohnsack \& Sutherland, 1985) and/or an increased food availability (Reubens et al., 2011). The production hypothesis suggests that the carrying capacity of the original environment increases due to the creation of the new habitats, favouring attraction and enhanced growth (Lindberg, 1997; Powers et al., 2003; Brickhill et al., 2005). These two hypotheses were put forward as the two extremes of a wide range of ecological processes (Svane \& Petersen, 2001; Brickhill et al., 2005). Attraction could for example, potentially facilitate production, since these two actions are not necessarily mutually exclusive (Svane
\& Petersen, 2001; Brickhill et al., 2005; Reubens et al., 2013c; Cresson et al., 2019). For example, if attraction towards the OWFs increases fish landings, in combination with fisheries prohibition/limitation (Samples \& Sproul, 1985), it could potentially lead to production.

Understanding the attraction-production hypotheses with respect to the artificial reefs at OWFs is crucial both for their efficient management and for the associated fisheries in the area (Cresson et al., 2014). So far, the attraction-production hypotheses have mainly been investigated by using stomach content analysis (Leitão et al., 2007; Reubens et al., 2011) and fish movement in close proximity to artificial reefs (Reubens et al., 2014b). However, approaching the attraction-production hypotheses by investigating the trophic relationships on artificial reefs and the transfer of organic matter from producers to consumers with the use of tracers has only been recently studied in oil and gas platforms the Gulf of Mexico (Daigle et al., 2013; Dance et al., 2018; Reeves et al., 2019).

This study aims at determining whether five fish species that have been observed at high densities in close proximity to Belgian OWFs (Reubens et al., 2011; Kerckhof et al., 2018) feed on prey items exclusively associated with man-made hard substrates for a prolonged period of time (up to 6 months). The investigated fish species are pouting [Trisopterus luscus (Linnaeus, 1758)], cod (Gadus morhua Linnaeus, 1758), horse mackerel ]Trachurus trachurus (Linnaeus, 1758)], mackerel (Scomber scombrus Linnaeus, 1758) and sculpin ]Myoxocephalus scorpioides (Fabricius, 1780)], which are abundantly present in close proximity to OWFs in the North Sea and the Baltic Sea (Reubens et al., 2011; Bergström et al., 2013; Kerckhof et al., 2018). These species can be categorized according to their ecology into: (1) benthic fish, living exclusively on and near the bottom of the sea, i.e. sculpin (Gordon \& Duncan, 1985); (2) benthopelagic fish, living in close association with the sea floor, i.e. pouting and cod (Gordon \& Duncan, 1985) and (3) pelagic fish, occupying mid-water or surface water levels and performing diel vertical migrations, i.e. mackerel and horse mackerel (Dale \& Kaartvedt, 2000).

Research on the short-term feeding ecology is often reliant on stomach content analysis (SCA), providing a snapshot of the recently ingested (up to $10 \mathrm{~h}$ ) food items (Hyslop, 1980). SCA can provide a high 
taxonomic resolution (e.g. at the species level) of the ingested food items that may be difficult to attain with other methods (Lin et al., 2007). However, it also has multiple limitations, such as the requirement of high sampling frequencies in order to obtain a timeintegrated overview of the feeding habits of a species (St John, 1999; Parkyn et al., 2001; Daly et al., 2013) and a minimal indication of the assimilated dietary items (Parkyn et al., 2001; Jensen et al., 2012). Hence, stomach contents mainly consisting of hard substrate fouling organisms can be an indication of attraction towards the artificial structures for foraging activities.

The majority of the limitations of the SCA can be overcome by combining this method with stable isotope analysis (SIA). SIA has considerable advantages, showing a time- (up to 6 months) and space-integrated dietary estimation (Bearhop et al., 2004; Fry, 2006; Newsome et al., 2007), providing long-term information of a species feeding ecology. The time-integrated information can be acquired with a few samples (absolute minimum three replicates-Jackson et al., 2011) per species. A diet based on fouling fauna for a prolonged period could indicate a long-term residency close to artificial reefs, which is a clear indication of attraction, but could potentially also lead to increased local production. SIA provides information on the truly assimilated food items (Boecklen et al., 2011) and thus on the nutritionally important food sources (Melville \& Connolly, 2003; Daly et al., 2013). Moreover, it allows for investigating the isotopic niche of a species, which is a proxy for its trophic niche (Jackson et al., 2011). However, this method does not provide the high taxonomic resolution as provided by SCA (Daly et al., 2013). Thus, a combination of SIA and SCA is a powerful approach that can provide a complete picture of the feeding ecology of fish species and can improve the interpretation of aquatic food webs (Parkyn et al., 2001).

In this paper, we assessed the feeding ecology of the five fish species by using a combination of SCA and SIA. We aimed at investigating whether fish use artificial reefs as feeding grounds for prolonged periods, according to three assumptions: (a) fish species use artificial reefs as feeding grounds for a prolonged period when both the SCA and the SIA show similar results and the fish' diet relies on fouling fauna that only occurs on artificial hard substrates in the southern North Sea; (b) fish occasionally use artificial reefs as feeding grounds if SCA reflects diet composition on food items derived from artificial structures (i.e. fouling organisms) which is not confirmed by SIA; and (c) fish probably do not use the artificial reefs as feeding grounds if both methods reveal a diet based on food items that are not associated with artificial hard substrates.

\section{Methodology}

Sampling area and data collection

Sampling was conducted next to a gravity-based wind turbine (D6, coordinates: $51^{\circ} 33.04^{\prime} \mathrm{N}-02^{\circ} 55.42^{\prime} \mathrm{E}$ ) within the C-Power wind farm at the Thornton Bank at the Belgian part of the North Sea (BPNS). The gravitybased foundation has a diameter of $6 \mathrm{~m}$ at the sea surface increasing to $14 \mathrm{~m}$ at the sea floor (Reubens et al., 2011), where it is surrounded by a rock collar forming the scour protection layer with a width of $62.5 \mathrm{~m}$ (SPL-Peire et al., 2009). We chose this particular location because a wealth of data on the investigated fish species was available (Reubens et al., 2011; Kerckhof et al., 2018).

Individuals of five species were collected during day time in August 2016: juvenile cod (Gadus morhua; length (mean $\pm \mathrm{SD}$ ): $320 \pm 35 \mathrm{~mm}$; weight (mean $\pm \mathrm{SD}$ ): $324 \pm 100 \mathrm{~g}$ ), pouting (Trisopterus luscus; length (mean $\pm \mathrm{SD}$ ): $237 \pm 30 \mathrm{~mm}$; weight (mean $\pm \mathrm{SD}): \quad 188 \pm 80 \mathrm{~g})$, mackerel (Scomber scombrus; length (mean \pm SD): $289 \pm 34 \mathrm{~mm}$; weight (mean $\pm \mathrm{SD}$ ): $221 \pm 66 \mathrm{~g}$ ) and horse mackerel (Trachurus trachurus; length (mean $\pm \mathrm{SD}$ ): $254 \pm 24 \mathrm{~mm}$; weight (mean $\pm \mathrm{SD}): 172 \pm 51 \mathrm{~g}$ ) were sampled from an inflatable boat at about $5 \mathrm{~m}$ from the turbine using fishing lines [hooks: Arca size 4, bait: Arenicola marina (Linnaeus, 1758)]. Sculpin (Myoxocephalus scorpioides; length (mean $\pm \mathrm{SD}$ ): $213 \pm 64 \mathrm{~mm}$; weight (mean \pm SD): $168 \pm 133 \mathrm{~g}$ ) was collected by spear-fishing by scientific divers since this benthic species lives in between the rocks of the scour protection layer. The benthopelagic species (cod and pouting) were collected above the scour protection layer, while the pelagic species (mackerel and horse mackerel) were sampled from ca. $10 \mathrm{~m}$ depth of the water column. Only cod juveniles, belonging to the I-group (i.e. $<50 \mathrm{~cm}$ (Reubens et al., 2013c), were sampled (from now on referred as cod). This size category is known to be abundantly 
frequent in the OWFs (Reubens et al., 2013c), while the older age groups (i.e. II-group and beyond) move towards other locations (Reubens et al., 2014b). Fish were immediately killed by pithing with a metal rod (Kadye \& Booth, 2012) and measured (total length in $\mathrm{mm})$. Subsequently, fish stomachs were extracted and preserved in an $8 \%$ formaldehyde-seawater solution for the stomach content analysis (Reubens et al., 2011). A part of the dorsal (white) muscle without skin of at least five individuals (from which we also collected the stomachs) per fish species was isolated for stable isotope analysis using a scalpel. The scalpel was cleaned with ethanol before every use (both between different species and between different individuals) to avoid cross-contamination. This tissue yields the lowest $\delta^{15} \mathrm{~N}$ and $\delta^{13} \mathrm{C}$ variability compared to other fish tissues, such as red muscle, liver and heart, and it is considered the best tissue for use in stable isotope analysis (Pinnegar \& Polunin, 1999). The muscle tissue was stored in a clean vial with filtered sea water in a $-20^{\circ} \mathrm{C}$ freezer until further analysis. Stomachs and muscles were extracted from similar sized individuals per species (see above) to exclude any size-related dietary shifts (Mittelbach \& Persson, 1998).

\section{Stomach content analysis}

For the short-term diet analysis, we obtained stomach content samples from 62 individuals in total (pouting: 17 ind.; cod: 16 ind.; horse mackerel: 12 ind.; mackerel: 12 ind.; sculpin: 7 ind.). The number of stomachs analysed was relatively small and deriving from individuals collected only in summer due to the logistic effort of collecting all consumers and food resources in all the seasons. When the small number of stomachs is unavoidable, pairing SCA with stable isotope analysis (SIA-Davis et al., 2012) can help validating trophic relationships elucidated through SCA (Clarke et al., 2005) and offer additional information on trophic flows and food sources (Dalsgaard et al., 2003; Melville \& Connolly, 2003; Abrantes et al., 2014).

In the laboratory, stomachs were dissected, cleaned three times with water to assure that they were empty, and the content was collected and rinsed thoroughly with milli-Q water. Stomach content samples were drained in a $90 \mu \mathrm{m}$ mesh sieve to thoroughly collect both the small zooplanktonic organisms and the half- digested parts of bigger organisms (i.e. crabs and fish). Consequently, they were immediately examined under a stereomicroscope to identify prey items to the lowest taxonomic level possible, and counted (Reubens et al., 2011; Rumolo et al., 2017). Since many prey individuals were incomplete (i.e. stomachs containing only the scales of fish or a cheliped from a decapod), we did not estimate the biomass contribution of prey species. Prey items were allocated into ten broader taxonomic groups ("Stable isotope analysis" section) to facilitate the analysis. The relative numerical abundance (\%), of each prey item in all non-empty stomachs of one species (Jardas et al., 2004) was estimated.

Differences in stomach content composition between the different fish species were visualized using non-metric multi-dimensional scaling (MDS) and tested using the one-way analysis of similarity (ANOSIM) routine. As the quantity of the prey items in the stomach contents varied across the fish individuals, the underlying Bray-Curtis similarity matrix (Clarke \& Gorley, 2006) was constructed based on relative prey abundance data per stomach (De Crespin De Billy et al., 2000). Following a significant ANOSIM result, pairwise tests were conducted to investigate possible diet overlap. We considered pairwise comparisons with $R<0.25$ as substantial dietary overlap and with $R>0.5$ indicating relatively minimal dietary overlap, while $0.25<R<0.5$ was considered moderate dietary overlap (Creque \& Czesny, 2012).

\section{Stable isotope analysis}

For the analysis of the more long-term trophic ecology of the five fish species, carbon $\left(\delta^{13} \mathrm{C}\right)$ and nitrogen $\left(\delta^{15} \mathrm{~N}\right)$ stable isotope analyses were performed (5 individuals of cod, pouting, horse mackerel and sculpin, and 11 individuals of mackerel). The frozen dorsal muscle tissue was thawed, rinsed with milli-Q water to remove salts (Nilsen et al., 2008) and dried overnight at $60^{\circ} \mathrm{C}$. The dried samples were grounded to a homogenous powder using a pestle and a mortar and approximately $1 \mathrm{mg}$ of dried tissue per individual per species was encapsulated in a $\mathrm{Sn}$ capsule $(8 \times 5 \mathrm{~mm}$, Elemental Microanalysis UK). The capsules were stored in multi-well microtitre plates until the isotopic analysis for $\delta^{13} \mathrm{C}$ and $\delta^{15} \mathrm{~N}$ was conducted at the UC Davis Stable Isotope Facility (University of California, USA) by a PDZ Europa ANCA-GSL 
elemental analyser, interfaced to a PDZ Europa 20-20 isotope ratio mass spectrometer (Sercon Ltd., Cheshire, UK). $\delta^{13} \mathrm{C}$ and $\delta^{15} \mathrm{~N}$ data are expressed in the standard delta $(\delta)$ notation relative to standard reference material: Vienna Pee Dee Belemnite for carbon and atmospheric $\mathrm{N}$ for nitrogen. The results are expressed in parts per thousand (\%) according to the following equation:

$\delta X=\left[\left(R_{\text {Sample }} / R_{\text {Standard }}\right)-1\right] \times 10^{3}$

where $X$ is ${ }^{13} \mathrm{C}$ or ${ }^{15} \mathrm{~N}$ and $R$ is the corresponding ratio of ${ }^{13} \mathrm{C} /{ }^{12} \mathrm{C}$ or ${ }^{15} \mathrm{~N} /{ }^{14} \mathrm{~N}$.

The trophic niches of the five fish species were estimated using the stable isotope Bayesian ellipses package in R (SIBER package, Jackson et al., 2011). SIBER generates sample size-corrected standard ellipse areas $\left(\mathrm{SEA}_{\mathrm{C}}\right)$ that were used to estimate the isotopic niche size and the trophic overlap between the five fish species. $\mathrm{SEA}_{\mathrm{C}}$ nullifies the bias created from small sample sizes $(n>3)$ and reflects the isotopic niche of a population, which is considered a proxy of its trophic niche (Jackson et al., 2011). By estimating the $\mathrm{SEA}_{\mathrm{C}}$ overlap, we obtained information about the isotopic niche overlap between the different fish species. Results are expressed as mean \pm standard deviation (SD).

The relative contribution of each prey item to the diet of the different fish species was estimated using stable isotope mixing models in R (SIMMR package, Parnell et al., 2013). SIMMR can incorporate the variability that is associated with consumers, sources and trophic enrichment factors (TEFs, Parnell et al., 2013). By using Markov Chain Monte Carlo simulations, this model can determine the potential contribution of different sources to the diet of a consumer (Parnell et al., 2010). As the isotopic composition of the fish species was measured by using muscle tissues, the diet estimates represent the proportion of the sources that have been assimilated by this tissue (Lamontagne et al., 2016). This tissue has slower turnover rates than other body parts, and thus, its isotopic signature reflects a longer-term diet history than tissues with faster turnover rates (Bruestle et al., 2018). SIMMR considers the mean $\left(\mu_{\text {prey }}\right)$ and the standard deviation $\left(\sigma_{\text {prey }}\right)$ of the stable isotope ratios of the prey species for the estimation of the proportion of a given prey in the diet (Parnell et al., 2013; Lamontagne et al., 2016).
However, this model is based on the assumption that all the food resources are included in the analysis (Phillips et al., 2014). In order to meet this assumption, we used the food items that were identified by the SCA in the stomachs of juvenile cod, pouting, horse mackerel and sculpin as prior information for the SIMMR (Jensen et al., 2012). For mackerel, though, we also included uncountable prey items that were not identified in their stomachs to meet the assumption of the model that the consumers' mixtures fall within the polygon of the prey items. Food resources representing $<1 \%$ of the stomach contents per species were not included in the mixing models. The prey items were grouped into 10 broad taxonomic categories: Amphipoda, Bivalvia, Cumacea, Decapoda, Echinodermata, Gastropoda, Hydrozoa, Nematoda (i.e. soft sediment and hard substrate benthos), and the pelagic prey items Fish and Zooplankton. Partially digested prey individuals that could not be allocated to one of these groups were not further considered. For mackerel, no prior information deriving from the SCA was used for the mixing model to meet the assumption that the mixtures of the consumer fall within the polygon of the prey items. Therefore, more prey items, such as suspended particulate organic matter from surface and bottom waters (SPOM-surface and SPOM-bottom, respectively), were considered as potential prey items for this species.

The prey items included in the mixing models of all the fish species were already a mixture of isotopically similar sources. This grouping was performed because the discriminatory power of the mixing models decreases with the number of food sources (Phillips et al., 2014). Furthermore, an a posteriori combination of prey items was performed when a strong negative correlation indicated that the prey items were isotopically similar and, thus, were undistinguishable (Parnell et al., 2013). Stable isotope signatures of these broad taxonomic categories, zooplankton, SPOMsurface and SPOM-bottom, sampled during the same sampling event were obtained from Mavraki et al. (2020a, b), while nematodes, Cumacea and fish (Engraulidae) stable isotope data were acquired from Franco et al. (2008), Kürten et al. (2013) and Jennings and Cogan (2015), respectively (Table 1). The isotopic signatures of these prey items did not show a large variation (nematodes: $\delta^{13} \mathrm{C}:-18.0 \pm 1.0 \%$ and $\delta^{15} \mathrm{~N}: \quad 10.0 \pm 0.9 \%$; $\quad$ Cumacea: $\quad \delta^{13} \mathrm{C}: \quad-$ $13.18 \pm 0.2 \%$ and $\delta^{15} \mathrm{~N}: 9.68 \pm 0.1 \%$ o and fish: 
Table 1 Stable isotope carbon $\left(\delta^{13} \mathrm{C}\right)$ and nitrogen $\left(\delta^{15} \mathrm{~N}\right)$ mean and standard deviation (SD) values of the food items that were found in the stomach contents $(>1 \%)$ of all fish species and were included in the mixing model

\begin{tabular}{llllll}
\hline Food item & mean $\delta^{13} \mathrm{C}$ & $\mathrm{SD} \delta^{13} \mathrm{C}$ & mean $\delta^{15} \mathrm{~N}$ & $\mathrm{SD} \delta^{15} \mathrm{~N}$ & References \\
\hline Amphipoda & -18.90 & 0.65 & 11.50 & 0.42 & Mavraki et al. (2020b) \\
Bivalvia & -19.45 & 0.54 & 10.88 & 0.22 & Mavraki et al. (2020b) \\
Cumacea & -15.50 & 0.20 & 9.20 & 0.30 & Kürten et al. (2013) \\
Decapoda & -20.80 & 1.53 & 11.66 & 0.73 & Mavraki et al. (2020a, b) \\
Fish & -21.28 & 1.52 & 10.18 & 1.35 & Jennings and Cogan (2015) \\
Hydrozoa & -19.00 & 0.72 & 9.87 & 0.50 & Mavraki et al. (2020b) \\
Nematoda & -18.00 & 1.00 & 10.00 & 1.00 & Franco et al. (2008) \\
Zooplankton & -19.50 & 0.56 & 11.20 & 0.30 & Mavraki et al. (2020a) \\
SPOM-surface & -22.30 & 0.30 & 11.28 & 0.24 & Mavraki et al. (2020a) \\
SPOM-bottom & -21.44 & 1.27 & 10.67 & 0.18 & Mavraki et al. (2020a) \\
\hline
\end{tabular}

$\delta^{13} \mathrm{C}:-18.8 \pm 1.1 \%$ and $\delta^{15} \mathrm{~N}: \quad 11.7 \pm 0.3 \%$ ) assuring that the results would not be affected by using bulk food resources. We further constrained the mixing model with the known dietary proportions for juvenile cod, pouting, horse mackerel and sculpin acquired by the SCA using the function simmr_elicit (Parnell \& Inger, 2019).

Trophic enrichment factors (TEFs) were added to the mixing models. Mixing models are sensitive to assumptions regarding TEFs (Phillips et al., 2014) because of the multiplicity of factors that can affect them (Phillips et al., 2014). Hence, the use of the most appropriate TEF is crucial to produce the most accurate results. In order to accomplish this, we used the function simmr_mcm_tdf that can estimate the most appropriate TEF values for a known set of dietary proportions (Parnell \& Inger, 2019). Hence, every species had different mean and standard deviation values of TEFs (Table 2). The TEFs defined by the model were within the reported range of -1 to $6 \%$ for nitrogen and -0.8 to $4 \%$ for carbon (Caut et al., 2009). The use of these TEFs assured that the fish' isotopic ratios fitted within the polygon of the prey items (Fig. S1), which is one of the prerequisite of isotopic mixing models (Phillips et al., 2014). Furthermore, the use of the functions simmr_elicit and simmr_mcm_tdf assured that the density distributions were not constrained (Fig. S2). The isotopic niche and the dietary proportion estimations were performed in R (R Development Core Team, 2018). The diet proportions are reported as the mean and standard deviation, but also as the median (50th percentile) and the $95 \%$ credible intervals $(2.5$ th and 97.5 th percentiles) to avoid misinterpretations of unique (mean) values (Phillips \& Gregg, 2003; Phillips et al., 2014).

\section{Results}

Diet analysis of the fish species

The SCA showed that the stomachs of the individuals of sculpin contained the lowest, and pouting the highest number of food items. Pouting, juvenile cod and horse mackerel stomachs mainly had the amphipod Jassa herdmani (Walker, 1893) (87.6 $\pm 10.2 \%$,

Table 2 Mean and standard deviation (SD) values of the $\delta^{13} \mathrm{C}$ and $\delta^{15} \mathrm{~N}$ trophic enrichment factors (TEFs) for every consumer species

\begin{tabular}{lllll}
\hline Consumer species & Mean $\delta^{13} \mathrm{C}$ TEF & $\mathrm{SD} \delta^{13} \mathrm{C}$ TEF & Mean $\delta^{15} \mathrm{~N}$ TEF & SD $\delta^{15} \mathrm{~N}$ TEF \\
\hline Gadus morhua & 2.99 & 0.51 & 5.77 & 0.86 \\
Myoxocephalus scorpioides & 4.36 & 0.73 & 5.50 & 2.04 \\
Scomber scombrus & 0.62 & 0.43 & 3.68 & 1.23 \\
Trachurus trachurus & 0.79 & 0.57 & 5.82 & 0.98 \\
Trisopterus luscus & 3.35 & 0.50 & 6.21 & 1.00 \\
\hline
\end{tabular}


$76.2 \pm 19.3 \%$ and $61.2 \pm 26.5 \%$, respectively), while other amphipod species such as Monocorophium acherusicum (Costa, 1853), Stenothoe valida (Dana, 1852) and Phtisica marina (Slabber, 1769) were observed in smaller quantities. Mackerel stomach content was dominated by zooplankton $(83.9 \pm 8.3 \%)$, while sculpin stomachs mainly contained both Pisidia longicornis (Linnaeus, 1767) $(40.0 \pm 11.3 \%)$ and fish $(30.0 \pm 10.0 \%$-Table 3$)$. After allocating the prey items to broader taxonomic groups (see "Stable isotope analysis" section), the stomach contents of sculpin showed the lowest variety (3 prey groups); highest prey group variety (9 groups) was observed for juvenile cod (Fig. 1). Occasionally, empty stomachs were found. One empty stomach was found for cod and mackerel, while the stomachs of three sculpins were empty as well.

ANOSIM revealed significant differences in the stomach contents of the different fish species (Fig. 2Global $R=0.244, P=0.001$ ). The pairwise tests indicated dietary overlaps between cod, horse mackerel and pouting. Moreover, dietary overlap was also observed between cod, horse mackerel and sculpin (pairwise $R$ values $<0.25$ ) (Table 4). Moderate dietary overlap was found between mackerel, horse mackerel and cod $(0.25<R<0.5)$, while low overlap was observed between mackerel and sculpin and pouting (pairwise $R>0.5$ ).

Isotopic niches

Five individuals of cod, horse mackerel, sculpin and pouting and eleven mackerels were analysed for $\mathrm{C}$ and $\mathrm{N}$ stable isotopes (Table 5, Fig. 3a). The lowest mean $\delta^{13} \mathrm{C}$ values and $\delta^{15} \mathrm{~N}$ values were observed for mackerel $\left(\delta^{13} \mathrm{C}: \quad-20.5 \pm 2.2 \%\right.$ and $\delta^{15} \mathrm{~N}$ : $16.0 \pm 3.7 \%$ ), while the highest mean $\delta^{13} \mathrm{C}$ and $\delta^{15} \mathrm{~N}$ values (observed for all the fish individuals) were found for sculpin $\left(\delta^{13} \mathrm{C}\right.$ : $-15.8 \pm 0.3 \%$ and $\delta^{15} \mathrm{~N}$ : $18.4 \pm 1.7 \%$ o). The pelagic fish species generally had depleted $\delta^{13} \mathrm{C}$ values in comparison to the benthic and benthopelagic species. Mackerel was the species with the highest variability in the $\delta^{15} \mathrm{~N}$ values, while the $\delta^{15} \mathrm{~N}$ signatures of the other species did not differ remarkably.

Standard ellipse areas corrected for small sample sizes $\left(\mathrm{SEA}_{\mathrm{C}}\right.$ ) (a proxy of the trophic niches) indicated differences between the five fish species (Fig. 3b, Table 6). The smallest $\operatorname{SEA}_{\mathrm{C}}\left(0.22 \%^{2}\right)$ was observed for cod, followed by pouting $\left(0.88 \%{ }^{2}\right)$. The largest $\operatorname{SEA}_{C}\left(24.64 \%^{2}\right)$ was observed for mackerel. Generally, high overlaps were observed between the isotopic niches of the species with the same ecology (Table 6, Fig. 3b). The isotopic niche of the benthic species sculpin was the only one that did not overlap with any of the isotopic niches of the other species.

Dietary proportions from SCA and SIA combination

The Bayesian stable isotope mixing models (SIMMR) results, as indicated with the use of informative priors, suggested that fouling "Amphipoda" contributed the most to the diet of cod $(84.4 \pm 4.7 \%)$. The combination of fouling "Amphipoda" and "Decapoda", named as "Fouling Crustaceans", was the main prey item in the diet of pouting $(95.9 \pm 3.1 \%)$, while the combination of fouling "Amphipoda" and "Zooplankton", called here "Small Crustaceans", significantly contributed to the diet of horse mackerel (79.4 $\pm 4.7 \%$-Fig. 4, Table 7). "Decapoda" was the second most important prey item in the diet of $\operatorname{cod}(12.8 \pm 3.8 \%)$, however, with remarkably lower contribution to its diets. The diet of horse mackerel partly relied on "Fish" $(7.8 \pm 1.9 \%)$ and "Decapoda" $(7.7 \pm 3.1 \%)$, but in notably lower contributions than "Small Crustaceans". The diet of sculpin was mainly based on benthic "Decapoda" $(66.3 \pm 4.7 \%)$, but "Fish" was also an important prey item $(27.3 \pm 3.7 \%)$. Mackerel was the only species that exploited equal shares of most of the prey items (apart from "Nematoda") included in the model. Its diet was, however, largely based on pelagic prey items, i.e. "Zooplankton" $(18.1 \pm 3.5 \%)$, "SPOM-surface" $(20.6 \pm 6.2 \%)$ and "SPOM-bottom" $(17.0 \pm 1.6 \%)$. These prey items contributed on average more than $50 \%$ to mackerel's diet. All the other prey items were assessed to be of minor importance $(<12.8 \%)$ in the diet of the different fish species.

\section{Discussion}

Our study showed that two benthopelagic (cod and pouting) and one benthic (sculpin) fish species use artificial hard substrates, such as those in the OWFs, as feeding grounds for a prolonged period, since both the short- (stomach content analysis) and the long- 
Table 3 List of prey items. Percentage (\%) and standard deviation of abundance of consumed items in the diets of the five different fish species

\begin{tabular}{|c|c|c|c|c|c|}
\hline & \multicolumn{2}{|l|}{ Pelagic } & \multicolumn{2}{|c|}{ Benthopelagic } & \multirow{2}{*}{$\begin{array}{l}\text { Benthic } \\
\text { Myoxocephalus } \\
\text { scorpioides }\end{array}$} \\
\hline & $\begin{array}{l}\text { Scomber } \\
\text { scombrus }\end{array}$ & $\begin{array}{l}\text { Trachurus } \\
\text { trachurus }\end{array}$ & $\begin{array}{l}\text { Gadus } \\
\text { morhua }\end{array}$ & $\begin{array}{l}\text { Trisopterus } \\
\text { luscus }\end{array}$ & \\
\hline \multicolumn{6}{|l|}{ Amphipoda } \\
\hline Jassa herdmani & 2.7 & $61.2 \pm 26.5$ & $76.2 \pm 19.3$ & $87.6 \pm 10.2$ & - \\
\hline $\begin{array}{c}\text { Monocorophium } \\
\text { acherusicum }\end{array}$ & - & 1.2 & 0.6 & 0.5 & - \\
\hline Phtisica marina & - & - & 0.3 & $1.2 \pm 0.2$ & - \\
\hline Stenothoe valida & - & - & $2.5 \pm 1$ & 0.2 & - \\
\hline Unidentified sp. & - & $2.2 \pm 1.5$ & - & 0.1 & - \\
\hline \multicolumn{6}{|l|}{ Bivalvia } \\
\hline Aequipecten opercularis & - & - & - & 0.3 & - \\
\hline Crepidula fornicata & - & - & - & 0.1 & - \\
\hline Mytilus edulis & - & - & $0.4 \pm 0.1$ & 0.3 & 10.0 \\
\hline Unidentified sp. & - & - & $0.4 \pm 0.3$ & - & - \\
\hline \multicolumn{6}{|l|}{ Cumacea } \\
\hline Unidentified sp. & - & 1.2 & - & - & - \\
\hline \multicolumn{6}{|l|}{ Decapoda } \\
\hline Astacidea & - & - & - & 0.1 & - \\
\hline Liocarcinus sp. & - & $1.2 \pm 0.6$ & - & 0.2 & - \\
\hline Macropodia sp. & - & - & - & 0.4 & - \\
\hline Megalopa sp. & - & $1.2 \pm 1$ & - & - & - \\
\hline Pagurus sp. & - & - & 0.1 & - & - \\
\hline Pilumnus hirtellus & - & - & 0.1 & - & - \\
\hline Pisidia longicornis & - & $5.9 \pm 2.8$ & $15.3 \pm 9.7$ & $4.7 \pm 1.6$ & $40.0 \pm 11.3$ \\
\hline Processa modica & - & - & - & 0.1 & $10.0 \pm 3.6$ \\
\hline Unidentified sp. & 1.3 & $1.2 \pm 1$ & 0.4 & - & $10.0 \pm 2.4$ \\
\hline \multicolumn{6}{|l|}{ Echinodermata } \\
\hline Ophiothrix fragilis & - & - & 0.7 & - & - \\
\hline \multicolumn{6}{|l|}{ Gastropoda } \\
\hline Unidentified sp. & - & - & 0.1 & - & - \\
\hline \multicolumn{6}{|l|}{ Hydrozoa } \\
\hline Sertularia cupressina & - & - & - & 0.1 & - \\
\hline Tubularia sp. & - & - & $1.2 \pm 0.2$ & $2.1 \pm 1$ & - \\
\hline \multicolumn{6}{|l|}{ Nematoda } \\
\hline Unidentified sp. & $2.6 \pm 1.7$ & $5.9 \pm 1.6$ & 0.4 & 0.1 & - \\
\hline \multicolumn{6}{|l|}{ Pisces } \\
\hline Engraulidae & $4.0 \pm 1.2$ & - & - & - & - \\
\hline Unidentified sp. & $6.7 \pm 2.4$ & $9.4 \pm 4.5$ & 0.8 & $1.2 \pm 0.2$ & $30.0 \pm 10.0$ \\
\hline \multicolumn{6}{|l|}{ Zooplankton } \\
\hline Unidentified sp. & $83.9 \pm 8.3$ & $9.4 \pm 6.3$ & 0.4 & 0.1 & - \\
\hline
\end{tabular}




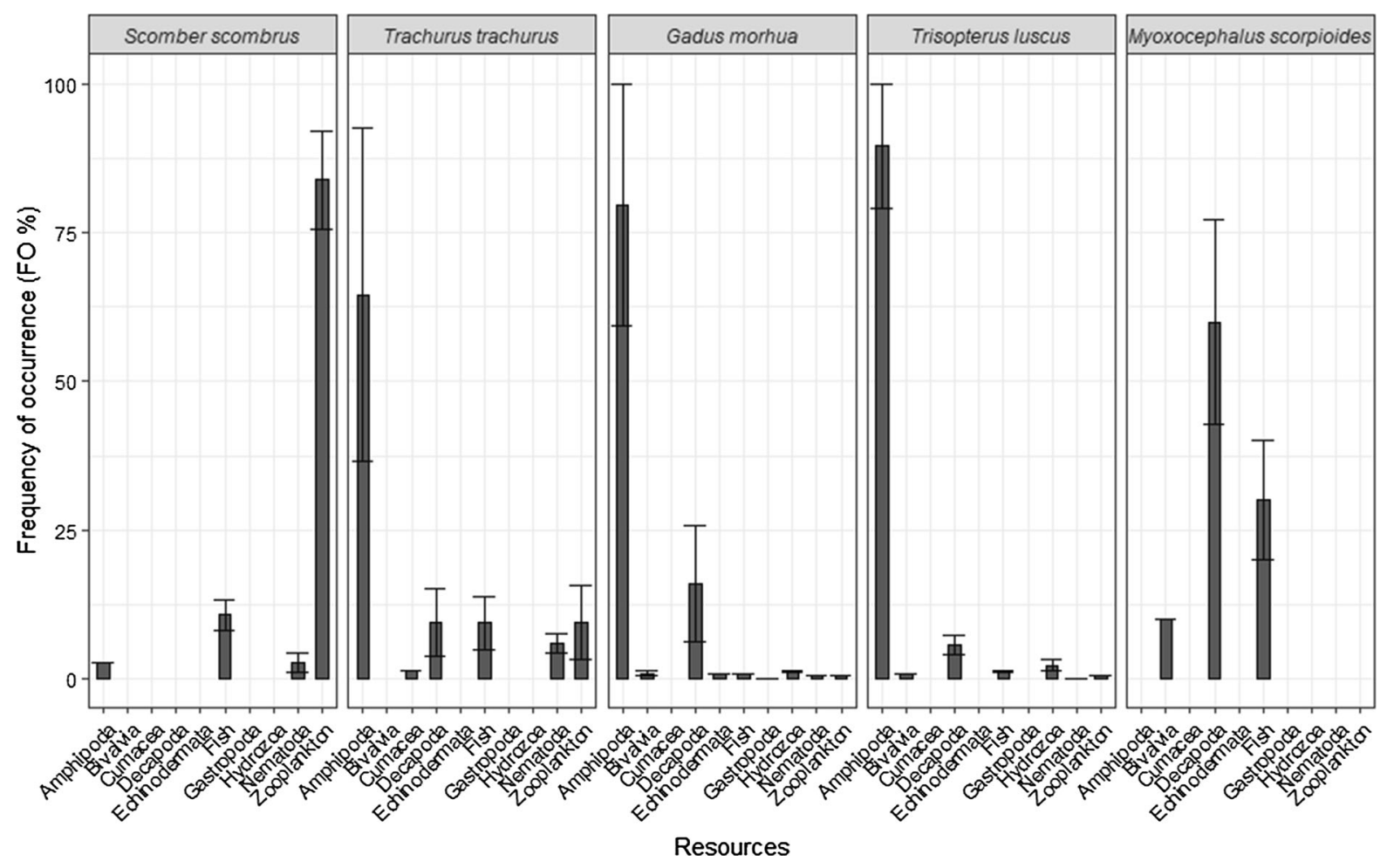

Fig. 1 Percentage of abundance (\%) of the broad taxonomic categories of the prey items found in the stomach contents of each of the five fish species, the benthic Myoxocephalus scorpioides, the benthopelagic Gadus morhua and Trisopterus luscus, and the pelagic Scomber scombrus and Trachurus trachurus. The error bars represent the standard deviation

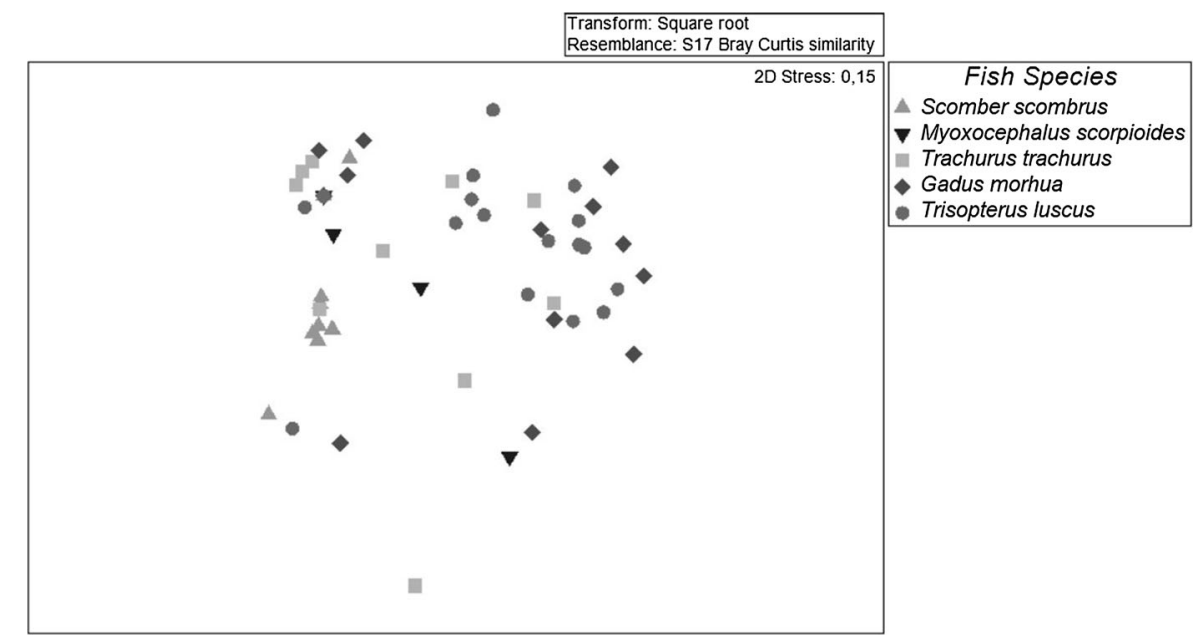

Fig. 2 Diet composition similarity of the five fish species as visualized by the non-metric multi-dimensional scaling (MDS). The different symbols represent different species

term (stable isotope analysis) dietary analyses suggested that their diets are based on fouling organisms. The pelagic horse mackerel seems to feed in the OWF area only opportunistically since the short-term (stomach content analysis) and the time-integrated (stable isotope analysis) studies showed contradictory results. Finally, the pelagic mackerel was found to mainly feed on pelagic food items (zooplankton, 
Table 4 Results of the one-way analysis of similarity (ANOSIM) pairwise comparisons between the diets of the different fish species. Global $R=0.244, P=0.001$

\begin{tabular}{lr}
\hline Groups & R statistic \\
\hline Scomber scombrus, Myoxocephalus scorpioides & 0.611 \\
Scomber scombrus, Trachurus trachurus & 0.261 \\
Scomber scombrus, Gadus morhua & 0.375 \\
Scomber scombrus, Trisopterus luscus & 0.582 \\
Myoxocephalus scorpioides, Trachurus trachurus & -0.076 \\
Myoxocephalus scorpioides, Gadus morhua & -0.034 \\
Myoxocephalus scorpioides, Trisopterus luscus & 0.505 \\
Trachurus trachurus, Gadus morhua & -0.023 \\
Trachurus trachurus, Trisopterus luscus & 0.198 \\
Gadus morhua, Trisopterus luscus & 0.066 \\
\hline
\end{tabular}

SPOM-surface and SPOM-bottom), which suggests that it might not exploit the artificial hard structures as feeding habitats.

The stomach content analysis derived from a limited number of individuals that have been collected during day time in a single season (summer), hence not necessarily fully reflecting the natural dietary variability. Increasing the number of stomach samples would result in a more reliable representation of the actual diet (Ferry \& Cauilliet, 1996). However, this was not possible in this study due to the logistic efforts mentioned above. While the number of replicates was small, the stomach content results pointed in the same direction as previous dietary studies for these five species. Furthermore, the stomach contents did not

Table 5 Stable carbon $\left(\delta^{13} \mathrm{C}\right)$ and nitrogen $\left(\delta^{15} \mathrm{~N}\right)$ signatures $(\%$, mean and standard deviation) and number of samples $(n)$ of the five fish species collected at the offshore wind turbine

\begin{tabular}{llrr}
\hline Species & \multicolumn{1}{l}{$\delta^{13} \mathrm{C}$} & $\delta^{15} \mathrm{~N}$ & Number of individuals \\
\hline Gadus morhua & $-16.4 \pm 0.2$ & $17.2 \pm 0.6$ & 5 \\
Myoxocephalus scorpioides & $-15.8 \pm 0.3$ & $18.4 \pm 1.7$ & 5 \\
Scomber scombrus & $-20.5 \pm 2.2$ & $16.0 \pm 3.7$ & 11 \\
Trachurus trachurus & $-19.4 \pm 1.5$ & $16.9 \pm 0.8$ & 5 \\
Trisopterus luscus & $-16.8 \pm 0.3$ & $17.5 \pm 0.7$ & 5 \\
\hline
\end{tabular}
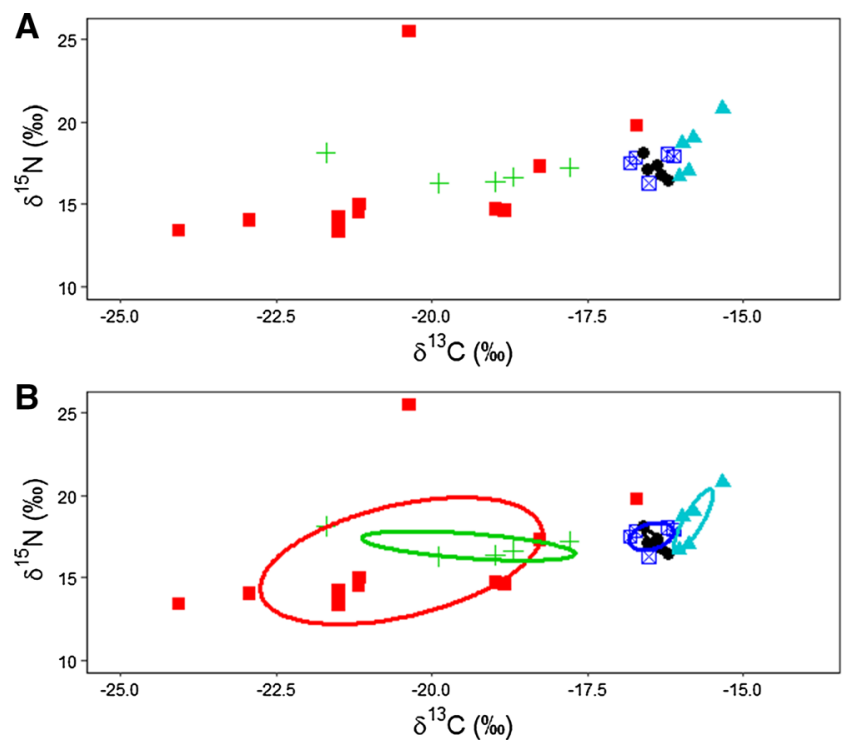

Species

- Gadus morhua

Myoxocephalus scorpioides

- Scomber scombrus

+ Trachurus trachurus

Trisopterus luscus

Fig. 3 a Individual $\delta^{13} \mathrm{C}$ versus $\delta^{15} \mathrm{~N}$ values and $\mathbf{b}$ standard ellipse areas corrected for small size samples $\left(\mathrm{SEA}_{\mathrm{C}}\right)$ of the five targeted fish species 
Table 6 Standard ellipse areas corrected for small size samples $\left(\mathrm{SEA}_{\mathrm{C}}-\%_{0}{ }^{2}\right)$ and overlaps $\left(\%_{0}{ }^{2}\right)$ between the isotopic niches of the different fish species collected at the offshore wind turbine

\begin{tabular}{|c|c|c|c|c|}
\hline Species 1 & Species 2 & $\mathrm{SEA}_{\mathrm{C}} 1\left(\%^{2}\right)$ & $\mathrm{SEA}_{\mathrm{C}} 2\left(\%^{2}\right)$ & Overlap $\left(\%^{2}\right)$ \\
\hline Gadus morhua & Myoxocephalus scorpioides & 0.22 & 1.03 & 0 \\
\hline Gadus morhua & Scomber scombrus & 0.22 & 24.64 & 0 \\
\hline Gadus morhua & Trachurus trachurus & 0.22 & 4.07 & 0 \\
\hline Gadus morhua & Trisopterus luscus & 0.22 & 0.88 & 0.16 \\
\hline Myoxocephalus scorpioides & Scomber scombrus & 1.03 & 24.64 & 0 \\
\hline Myoxocephalus scorpioides & Trachurus trachurus & 1.03 & 4.07 & 0 \\
\hline Myoxocephalus scorpioides & Trisopterus luscus & 1.03 & 0.88 & 0 \\
\hline Scomber scombrus & Trachurus trachurus & 24.64 & 4.07 & 3.54 \\
\hline Scomber scombrus & Trisopterus luscus & 24.64 & 0.88 & 0 \\
\hline Trachurus trachurus & Trisopterus luscus & 4.07 & 0.88 & 0 \\
\hline
\end{tabular}
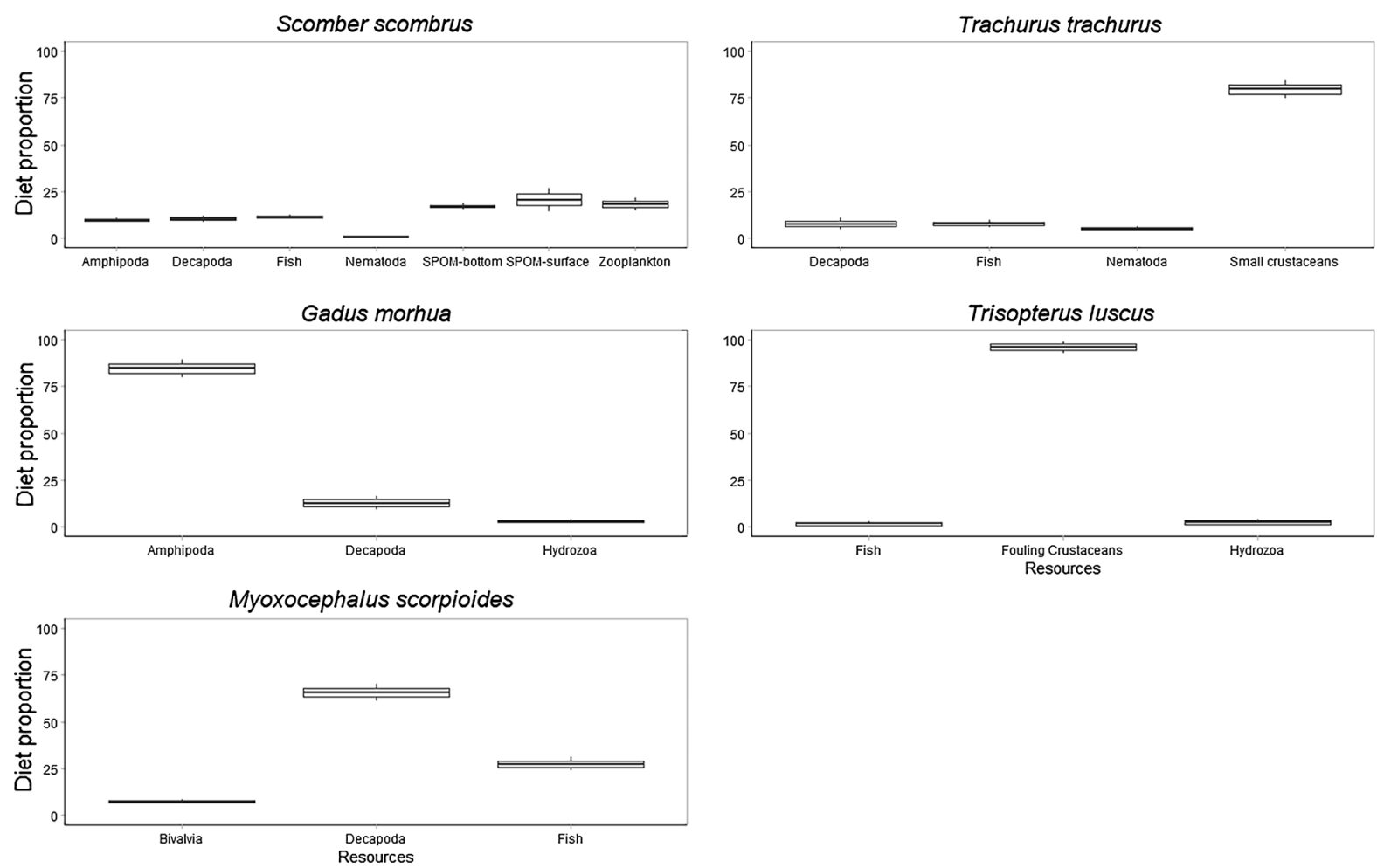

Fig. 4 Potential contribution of prey items on the diet of the pelagic species mackerel (Scomber scombrus) and horse mackerel (Trachurus trachurus), the benthopelagic cod (Gadus morhua) and pouting (Trisopterus luscus) and the benthic sculpin (Myoxocephalus scorpioides) as estimated by the

differ remarkably between individuals of the same species, hence illustrating the reliability of our results.

The stable isotope analysis was based on a small number of replicates, which, however, was always

stable isotope mixing models. The boxplots represent the credible intervals $25-75 \%$ of the dietary proportions, while the whiskers represent the $1.5^{*}$ Interquartile ranges (IQR) of the upper and lower quartile

higher than the absolute minimum sample size $(n>3$, Jackson et al., 2011). The SIA results suggested a clear dietary separation of the fish species according to their ecology. The isotopic signatures of the benthic 
Table 7 Proportion of prey categories in the diet of the five fish species sampled at close proximity from the offshore wind turbine as estimated by the combination of stomach content analysis and stable isotope mixing models

\begin{tabular}{|c|c|c|c|c|c|}
\hline Consumer species & Prey category & Mean $\pm \mathrm{SD}$ & 2.5th percentile & 50th percentile & 97.5th percentile \\
\hline \multirow[t]{3}{*}{ Gadus morhua } & Amphipoda & $84.4 \pm 4.7$ & 74.0 & 85.0 & 92.0 \\
\hline & Decapoda & $12.8 \pm 3.8$ & 6.6 & 12.4 & 21.4 \\
\hline & Hydrozoa & $2.8 \pm 1.1$ & 1.3 & 2.6 & 5.3 \\
\hline \multirow[t]{3}{*}{ Myoxocephalus scorpioides } & Bivalvia & $6.5 \pm 1.1$ & 4.6 & 6.4 & 8.7 \\
\hline & Decapoda & $66.3 \pm 4.7$ & 56.9 & 66.3 & 75.1 \\
\hline & Fish & $27.3 \pm 3.7$ & 20.2 & 27.2 & 34.8 \\
\hline \multirow[t]{7}{*}{ Scomber scombrus } & Amphipoda & $9.5 \pm 1.1$ & 1.1 & 8.6 & 11.8 \\
\hline & Decapoda & $10.4 \pm 1.6$ & 1.1 & 8.6 & 12.7 \\
\hline & Fish & $11.4 \pm 1.0$ & 1.1 & 8.4 & 13.7 \\
\hline & Nematoda & $0.9 \pm 0.4$ & 0.1 & 0.8 & 1.4 \\
\hline & Zooplankton & $18.1 \pm 3.5$ & 2.3 & 12.5 & 23.4 \\
\hline & SPOM-surface & $20.6 \pm 6.2$ & 2.6 & 16.0 & 28.3 \\
\hline & SPOM-bottom & $17.0 \pm 1.6$ & 2.3 & 11.6 & 19.2 \\
\hline \multirow[t]{4}{*}{ Trachurus trachurus } & Small Crustaceans & $79.4 \pm 4.7$ & 69.3 & 79.8 & 87.4 \\
\hline & Decapoda & $7.7 \pm 3.1$ & 3.1 & 7.2 & 15.3 \\
\hline & Fish & $7.8 \pm 1.9$ & 4.7 & 7.7 & 12.0 \\
\hline & Nematoda & $5.1 \pm 1.3$ & 2.9 & 4.9 & 8.0 \\
\hline \multirow[t]{3}{*}{ Trisopterus luscus } & Fouling Crustaceans & $95.9 \pm 3.1$ & 87.5 & 96.8 & 99.3 \\
\hline & Fish & $1.6 \pm 1.5$ & 0.2 & 1.2 & 5.7 \\
\hline & Hydrozoa & $2.4 \pm 1.8$ & 0.4 & 1.9 & 7.2 \\
\hline
\end{tabular}

Bold values indicate the highest percentages of the food items as they were identified bythe mixing models

(sculpin) and benthopelagic (pouting and juvenile cod) species indicated a diet based on artificial hard substrate prey items, while that of mackerel and horse mackerel showed pelagic feeding preferences. The $\delta^{13} \mathrm{C}$ value of sculpin is characteristic of a benthic diet, which is explained by the exploitation of the crab Pisidia longicornis that consumes sediment organic carbon when it occurs at the scour protection layer (Mavraki et al., 2020a). The $\delta^{13} \mathrm{C}$ signatures of pouting and cod reflect the signature of the amphipod Jassa herdmani that mainly feeds on zooplankton when it is found on the turbine foundations (Mavraki et al., 2020a). The depleted $\delta^{13} \mathrm{C}$ values of the pelagic fish species indicate that they consume prey items that rely their diets on primary producers. Finally, the use of the informed priors in the mixing models did not affect the results of this study compared to conducting the models without the prior information. Hence our results were not biased towards more abundant but lower in biomass items in comparison with less numerous and larger prey items. Therefore, we are certain that our models highlighted the actual dietary proportions of the examined consumers.

Exploitation of the artificial habitats

The results of our study indicated that the benthopelagic species (pouting and juvenile cod) were mainly feeding on fouling organisms, and specifically on Jassa herdmani, while the benthic species (sculpin) was predominantly feeding on decapods, and especially on the porcelain crab Pisidia longicornis. Previous stomach content analyses of pouting and juvenile cod in the area have indicated similar results to ours, with $J$. herdmani being the most important food resource for these two benthopelagic species (Reubens et al., 2011, 2014a). Both J. herdmani and $P$. longicornis are exclusively associated with subtidal artificial hard substrates, such as wind turbine foundations and shipwrecks, where they occur in high densities (Leonhard \& Pedersen, 2006; Zintzen, 2007; De Mesel et al., 2015). They are, however, rather rare 
in natural hard substrate communities (Zintzen, 2007). Jassa herdmani and P. longicornis have sufficient lipid levels (2.83 and $3.19 \% \mathrm{WW}$, respectivelyHeirman, 2011) reflecting their essential energy content, which substantiates their importance as food items for highly mobile species, such as cod and pouting. Both SCA and SIA indicated remarkable dietary overlaps between cod and pouting, while SCA suggested a possible trophic competition between cod, sculpin and horse mackerel. However, the level of trophic competition depends on the degree of the foodresource availability (López-Jamar et al., 1984). Since $J$. herdmani and $P$. longicornis occur in the OWF area in high densities (Zintzen, 2007; De Mesel et al., 2015), consumers could exploit the same resources with no or limited competition (López-Jamar et al., 1984). This in combination with the sufficient energy levels that have been reported for both J. herdmani and P. longicornis (De Troch et al., 2013) supports the idea that there is no trophic competition between the fish species.

In addition to their abundance, J. herdmani and $P$. longicornis are energy- and fatty-acid-rich food resources (De Troch et al., 2013). Jassa herdmani contains substantial concentrations of the fatty acid docosahexaenoic acid (DHA-De Troch et al., 2013), which is an essential fatty acid for the eye development of many fish species, such as cod (O'BrienMacDonald et al., 2006). Pisidia longicornis, on the other hand, has higher lipid levels than J. herdmani (3.19 and $2.83 \% \mathrm{WW}$, respectively-Heirman, 2011) and contains considerable amounts of the essential fatty-acid eicosapentaenoic acid (EPA), which is an important fatty-acid for growth and fish development (Sargent et al., 1999). These two species contain higher lipid levels than the fouling species Monocorophium acherusicum and the J. herdmani mats (Heirman, 2011; De Troch et al., 2013). The energy content of $J$. herdmani and $P$. longicornis is also higher than that of food sources of pelagic origin, such as copepods (Michaud \& Taggart, 2007), and of soft substrate origin, such as brown shrimp (Crangon crangon (Linnaeus, 1758)) larvae (Urzúa \& Anger, 2013).

The pelagic horse mackerel seems to feed only occasionally on fouling organisms. This follows from the contradicting dietary results between the SCA (diet mainly based on fouling amphipods) and the SIA, as revealed by its isotopic niche (diet mainly composed of pelagic prey items-since the overlap of the isotopic niches of horse mackerel and mackerel was large). This was the only species for which SCA and SIA did not reveal similar results, confirming that both methods can yield complementary information on dietary compositions (Kadye \& Booth, 2012; Hertz et al., 2017). Discrepancy between SIA and SCA can be a result of the differences in assimilation efficiencies among the prey items (Hertz et al., 2017). This discrepancy could also derive from the similarities in the stable isotope ratios of zooplankton and Jassa herdmani (Mavraki et al., 2020a) resulting in a less reliable resolution of the SIA for these two main food resources and leading to the a posteriori combination of these two prey items in the mixing model. A final explanation could also be found in the feeding behaviour of horse mackerels. Horse mackerels are opportunistic feeders that modify their diets according to the availability of the food items (Rumolo et al., 2017), and they can feed on both benthic and pelagic prey items (Van Ginderdeuren et al., 2014). Some pelagic species, such as horse mackerels, may take advantage of areas with high food availability to acquire and store energy (Jardas et al., 2004). Fat and energy content of horse mackerels has been reported to be lowest during and after the spawning period in late spring and summer, when considerable energy is spent on reproduction, while it is highest in autumn (Abaunza et al., 2003). In the North Sea, the energy content of horse mackerels increases rapidly in August and September (Abaunza et al., 2003), which coincides with our sampling period (see "Sampling area and data collection" section). Hence, we suggest that horse mackerels occasionally use the artificial habitats of OWFs as feeding grounds, where they can benefit from the locally increased availability of energy-rich food sources (J. herdmani) to support their highly mobile life style. It is possible, though, that this is a seasonally recurring pattern that needs further research.

Mackerel was the only species that was not predominantly feeding on fouling organisms, as both the short- and the long-term analyses indicated a diet based on pelagic prey items, which are indeed known to be its main food sources (Van Ginderdeuren et al., 2014; Bachiller et al., 2018). Hence, the occurrence of the mackerel in the vicinity of the OWF installations may either be associated with the presence of other pelagic species in the area (Reubens pers. com.), 
supporting the meeting point hypothesis that has been suggested for pelagic fish species (Dagorn \& Fréon, 1999), or be linked to the enhanced protection against predation and the favourable current patterns that are provided by these habitats (Petersen \& Malm, 2006).

All the fish individuals in this study were caught in close proximity to an offshore wind foundation. However, in the Belgian part of the North Sea, different types of artificial hard substrates exist, providing high abundance of fouling organisms (Zintzen, 2007). More than 300 shipwrecks, mainly from the World Wars I and II (Zintzen, 2007), have been mapped in the area (Fig. S3), while it is possible that many more unmapped wrecks are present (Reubens, 2013). Some of the wrecks are situated within OWF areas (Fig. S3). Even though the catch rates of pouting and juvenile cod are significantly higher at OWFs compared to shipwrecks in the Belgian part of the North Sea (Reubens et al., 2013a), we cannot exclude that the fish were also foraging for food resources at shipwrecks instead of offshore wind foundations. The only exception could be cod, since research on the juvenile individuals' movement has shown strong residency towards the OWFs (Reubens et al., 2013b). Cod juveniles exhibit crepuscular movements towards the OWFs, increasing their foraging success and reducing the predation pressure (Reubens et al., 2014a) and, at the same time, they settle in the OWF area (Reubens et al., 2014b). The combination of these studies with our results could suggest that cods remain in the OWF area to forage for a prolonged period of time.

Overall, the results of this study indicate that there are two main pathways supporting the feeding ecology of the fish species associated with OWFs: the 'pelagic pathway' that was based on the consumption of prey items of pelagic origin, such as zooplankton and SPOM, and the 'benthic pathway' that was based on the local benthic production. Both these pathways could lead to local production, since the main benthic prey item, J. herdmani, is a suspension feeder that mainly consumes zooplankton (Mavraki et al., 2020a). Thus, organic matter of pelagic origin might significantly contribute as a food resource due to the predominance of suspension feeders on the artificial hard substrates. These findings are in line with earlier observations on the feeding ecology of fish species related to artificial habitats in the Mediterranean Sea (Cresson et al., 2014) and could provide an indication of the co-existence of attraction and production on the same artificial reef system (Cresson et al., 2019).

Attraction-production hypotheses

Offshore wind farms and other artificial reefs could potentially act as production sites for fish species (Leonhard \& Pedersen, 2006) that feed on the abundant fouling fauna. The production hypothesis can be supported when the artificial habitat contributes to an increasing biomass and/or abundance of fish (Svane \& Petersen, 2001) and the fishing pressure is limited (Samples \& Sproul, 1985). This is due to the increased feeding efficiency, survival rates of larvae and protection against predation at the artificial habitats, which encourage fish to settle and concentrate here (Brickhill et al., 2005; Petersen \& Malm, 2006). The feeding ecology of the benthic (sculpin) and benthopelagic (pouting and juvenile cod) species as revealed in this study, in combination with the prohibition of fisheries within the Belgian OWF area since 2009 (De Backer et al., 2019), could be an indication that these species could potentially increase their local production. This is due to their long-term feeding ecology, which suggests that they remain close to artificial habitats for a long period of time to feed on prey items exclusively occurring on manmade structures. Similar studies in the Gulf of Mexico have suggested that artificial reefs can increase fish production when fish exploit primary and secondary producers associated with the artificial habitat (Daigle et al., 2013; Dance et al., 2018). However, it should be noted that the artificial reefs might promote fish production but this does not necessarily lead to enhanced fish stocks. Increased fish production could take place not by adding new fish in the system but by protecting and enhancing growth of the already present individuals, leading to enhanced fish biomass (Powers et al., 2003).

Support for the production hypothesis has already been indicated for pouting and cod in the Belgian OWF area (De Troch et al., 2013; Reubens et al., 2013c). Specifically, research has shown that juvenile cod individuals indicate high residency and site fidelity in offshore wind foundations (Reubens et al., 2013b) and that they settle in the area, suggesting increased production in terms of additional recruitment of individuals (Reubens et al., 2014b). Furthermore, larger lengths and better fitness proxies (i.e. 
growth, condition index and diet) have been observed for pouting individuals in close proximity to OWFs compared to individuals occurring in sandy areas (Reubens et al., 2013c). Cod and pouting exploit lipidand fatty-acid-rich food sources (J. herdmani and $P$. longicornis) that can provide them with sufficient energy to sustain their metabolism and growth, and could also contribute to pouting's reproduction (De Troch et al., 2013). The combination of our findings with these previous studies could corroborate the production hypothesis.

The findings of our study imply that sculpins could also increase their local production within the artificial reef area of OWFs. Indeed, artificial habitats have been reported to have a positive effect on the production of benthic carnivores, due to the increased food availability and the low fishing mortality (Cresson et al., 2019). It is, thus, possible that artificial reefs, such as OWFs, could enhance the production of benthic species.

The results of our study corroborate the hypothesis that both attraction and production can co-exist on the same artificial reef, depending on the habits of every species (Cresson et al., 2019). It is suggested that benthic and benthopelagic species could have an increased production within OWFs, but this cannot be demonstrated for the pelagic species. The opposite patterns observed between pelagic and benthic/benthopelagic species are typical in natural reefs but were seldomly noticed for artificial reefs (Morris et al., 2018). Recently, similar patterns at the functional group-level have been observed for fish species at artificial reefs in the bay of Marseilles (Cresson et al., 2019), where pelagic species do not feed on fauna associated with artificial reefs. In our study, mackerel seems not to be predominantly feeding on artificial reef fauna, while horse mackerel exploits them opportunistically. Visual observations have shown that horse mackerels approach the offshore wind foundations to predate, taking advantage of the shade that the foundations offer (Reubens pers. comm.). Hence, the pelagic species seem to be attracted towards the offshore wind turbines, but further research is needed concerning their production in the area. Previous studies have indicated that the effect of artificial reefs on the production of pelagic zooplanktivores (i.e. mackerel and horse mackerel) is negligible (Powers et al., 2003), since most of these reefs are too small to significantly affect the pelagic communities
(Cresson et al., 2019). To conclude, further investigation is needed about whether and how the pelagic species exploit the artificial reefs.

\section{Conclusions}

Our results indicated that both benthopelagic (pouting and juvenile cod) and benthic species (sculpin) that occur abundantly at offshore wind farms (OWFs) use the artificial reefs as feeding grounds for a prolonged period, since stomach content analysis (SCA) and stable isotope analysis (SIA) reveal a diet that is based on fauna typically found on artificial hard substrates. These species mainly consume fouling amphipods and decapods, which are abundant on these substrates. High trophic niche overlap was observed between the benthopelagic species, while the trophic niche of sculpin was not overlapping with any of the trophic niches of the other species. The pelagic species in our study either consume fouling organisms occasionally but in large proportions, i.e. horse mackerel, or they do not exploit them predominantly, i.e. mackerel. In the case of horse mackerel, artificial reefs act as feeding oases, providing high availability of prey items. Mackerel is largely feeding on pelagic prey items even when it is found in close proximity to OWFs and hence, the reason of its attraction to the artificial hard substrates requires further investigation. These findings corroborate to the hypothesis that OWFs could potentially increase the local production of fish species and especially of benthopelagic and benthic species, while further research is necessary for the pelagic species.

Acknowledgements The authors would like to acknowledge the FaCE-It project-Functional Biodiversity in a Changing Sedimentary Environment: Implications for biogeochemistry and food webs in a managerial setting-funded by the Belgian Science Policy Office (BELSPO, contract BR/154/A1/FaCE-It). We would like to thank the crew of R.V. Simon Stevin for help with sampling. We are indebted to Emil De Borger, Elise Toussaint and Jan Ranson for help with the sampling and the isolation of the stomachs and muscle tissues. Finally, we also acknowledge Mar Santos, who conducted part of the stomach content analysis, and Francis Kerckhof and Danae Kapasakali for helping with the identification of the stomach contents.

Open Access This article is licensed under a Creative Commons Attribution 4.0 International License, which permits use, sharing, adaptation, distribution and reproduction in any medium or format, as long as you give appropriate credit to the 
original author(s) and the source, provide a link to the Creative Commons licence, and indicate if changes were made. The images or other third party material in this article are included in the article's Creative Commons licence, unless indicated otherwise in a credit line to the material. If material is not included in the article's Creative Commons licence and your intended use is not permitted by statutory regulation or exceeds the permitted use, you will need to obtain permission directly from the copyright holder. To view a copy of this licence, visit http://creativecommons.org/licenses/by/4.0/.

\section{References}

Abaunza, P., C. Gordo, L. Karlou-Riga, A. Murta, A. T. G. W. Eltink, E. Garcia Santamaria, M. T. Hammer, C. Lucio, P. Iversen, S. A. Molloy \& J. Gallo, 2003. Growth and reproduction of horse mackerel, Trachurus trachurus (Carangidae). Reviews in Fish Biology and Fisheries 13: 27-61.

Abrantes, K. G., A. Barnett \& S. Bouillon, 2014. Stable isotopebased community metrics as a tool to identify patterns in food web structure in east African estuaries. Functional Ecology 28: 270-282.

Bachiller, E., K. R. Utne, T. Jansen \& G. Huse, 2018. Bioenergetics modeling of the annual consumption of zooplankton by pelagic fish feeding in the Northeast Atlantic. PLOS ONE 13: e0190345.

Bearhop, S., C. E. Adams, S. Waldron, R. A. Fuller \& H. Macleod, 2004. Determining trophic niche width: a novel approach using stable isotope analysis. Journal of Applied Ecology 73: 1007-1012.

Bergström, L., F. Sundqvist \& U. Bergström, 2013. Effects of an offshore wind farm on temporal and spatial patterns in the demersal fish community. Marine Ecology Progress Series 485: 199-210.

Boecklen, W. J., C. T. Yarnes, B. A. Cook \& A. C. James, 2011. On the use of stable isotopes in trophic ecology. Annual Review of Ecology, Evolution, and Systematics 42: 411-440.

Bohnsack, J. A. \& D. L. Sutherland, 1985. Artificial reef research: a review with recommendations for future priorities. Bulletin of Marine Science 37: 11-39.

Brickhill, M. J., S. Y. Lee \& R. M. Connolly, 2005. Fishes associated with artificial reefs: attributing changes to attraction or production using novel approaches. Journal of Fish Biology 67: 53-71.

Bruestle, E. L., C. Karboski, A. Hussey, A. T. Fisk, K. Mehler, C. Pennuto \& D. Gorsky, 2018. Novel trophic interaction between lake sturgeon (Acipenser fulvescens) and nonnative species in an altered food web. Canadian Journal of Fisheries and Aquatic Sciences 76: 6-14.

Caut, S., E. Angulo \& F. Courchamp, 2009. Variation in discrimination factors $\left(\Delta^{15} \mathrm{~N}\right.$ and $\left.\Delta^{13} \mathrm{C}\right)$ : the effect of diet isotopic values and applications for diet reconstruction. Journal of Applied Ecology 46: 443-453.

Clarke, K. R. \& R. N. Gorley, 2006. PRIMER v6: User Manual/ Tutorial. PRIMER-E, Plymouth: 192.
Clarke, L. R., D. T. Vidergar \& D. H. Bennett, 2005. Stable isotopes and gut content show diet overlap among native and introduced piscivores in a large oligotrophic lake. Ecology of Freshwater Fish 14: 267-277.

Coolen, J. W. P., O. G. Bos, S. Glorius, W. Lengkeek, J. Cuperus, B. van der Weide \& A. Agüera, 2015. Reefs, sand and reef-like sand: a comparison of the benthic biodiversity of habitats in the Dutch Borkum Reef Grounds. Journal of Sea Research 103: 84-92.

Creque, S. M. \& S. J. Czesny, 2012. Diet overlap of non-native alewife with native yellow perch and spottail shiner in nearshore waters of southwestern Lake Michigan, 2000-2007. Ecology of Freshwater Fish 21: 207-221.

Cresson, P., S. Ruitton \& M. Harmelin-Vivien, 2014. Artificial reefs do increase secondary biomass production: mechanisms evidenced by stable isotopes. Marine Ecology Progress Series 509: 15-26.

Cresson, P., L. Le Direach, E. Rouanet, E. Goberville, P. Astruch, M. Ourgaud \& M. Harmelin-Vivien, 2019. Functional traits unravel temporal changes in fish biomass production on artificial reefs. Marine Environmental Research 145: 137-146.

Dagorn, L. \& P. Fréon, 1999. Tropical tuna associated with floating objects: a simulation study of the meeting point hypothesis. Canadian Journal of Fisheries and Aquatic Sciences 56: 984-993.

Daigle, S. T., J. W. Fleeger, J. H. Cowan \& P. Y. Pascal, 2013. What is the relative importance of phytoplankton and attached macroalgae and epiphytes to food webs on offshore oil platforms? Marine and Coastal Fisheries 5: 53-64.

Dale, T. \& S. Kaartvedt, 2000. Diel patterns in stage-specific vertical migration of Calanus finmarchicus in habitats with midnight sun. ICES Journal of Marine Science 57: 1800-1818.

Dalsgaard, J., M. St, G. John, D. Müller-Navarra Kattner \& W. Hagen, 2003. Fatty acid trophic markers in pelagic marine environment. Advances in Marine Biology 4: 225-340.

Daly, R., P. W. Froneman \& M. J. Smale, 2013. Comparative feeding ecology of bull sharks (Carcharhinus leucas) in the coastal waters of the Southwest Indian Ocean inferred from stable isotope analysis. PLoS ONE 8: 1-11.

Dance, K. M., J. R. Rooker, J. B. Shipley, M. A. Dance \& R. J. D. Wells, 2018. Feeding ecology of fishes associated with artificial reefs in the northwest Gulf of Mexico. PLoS ONE 13: 1-25.

Davis, A. M., M. L. Blanchette, B. J. Pusey, T. D. Jardine \& R. G. Pearson, 2012. Gut content and stable isotope analyses provide complementary understanding of ontogenetic dietary shifts and trophic relationships among fishes in a tropical river. Freshwater Biology 57: 2156-2172.

De Backer, A., H. Polet, K. Sys, B. Vanelslander \& K. Hostens, 2019. Fishing activities in and around Belgian offshore wind farms: trends in effort and landings over the period 2006-2017. In Degraer, S., R. Brabant, B. Rumes \& L. Vigin (eds), Environmental Impacts of Offshore Wind Farms in the Belgian Part of the North Sea: Marking a Decade of Monitoring, Research and Innovation. Royal Belgian Institute of Natural Sciences, OD Natural Environment, Marine Ecology and Management, Brussels: 31-46. 
De Crespin De Billy, V., S. Doledec \& D. Chessel, 2000. Biplot presentation of diet composition data: an alternative for fish stomach contents analysis. Journal of Fish Biology 56: 961-973.

De Mesel, I., F. Kerckhof, A. Norro, B. Rumes \& S. Degraer, 2015. Succession and seasonal dynamics of the epifauna community on offshore wind farm foundations and their role as stepping stones for non-indigenous species. Hydrobiologia 756: 37-50.

De Troch, M., J. T. Reubens, E. Heirman, S. Degraer \& M. Vincx, 2013. Energy profiling of demersal fish: a casestudy in wind farm artificial reefs. Marine Environmental Research 92: 224-233.

Dörjes, J., 1977. Über die bodenfauna des Borkum Riffgrundes (Nordsee). Senckenberg Marit 9: 1-17.

Ferry, L. A., \& Cailliet, G. M., 1996. Sample size and data analysis: are we characterizing and comparing diet properly? In MacKinley, D., \& K. Shearer (eds), Feeding Ecology and Nutrition in Fish. Symposium Proceedings.

Franco, M. A., K. Soetaert, D. Van Oevelen, D. Van Gansbeke, M. J. Costa, M. Vincx \& J. Vanaverbeke, 2008. Density, vertical distribution and trophic responses of metazoan meiobenthos to phytoplankton deposition in contrasting sediment types. Marine Ecology Progress Series 358: 51-62.

Fry, B., 2006. Stable Isotope Ecology, Vol. 521. Springer, New York.

Gordon, J. D. M. \& J. A. R. Duncan, 1985. The ecology of the deep-sea benthic and benthopelagic fish on the slopes of the Rockall Trough, Northeastern Atlantic. Progress in Oceanography 15: 37-69.

Heirman, E., 2011. Importance of windmill artificial reefs as feeding grounds for demersal fishes in the Belgian part of the North Sea. Master thesis, Department of Biology, Faculty of Sciences, Ghent University, Ghent, Belgium: 33.

Hertz, E., M. Trudel, S. Tucker, T. D. Beacham \& A. Mazumder, 2017. Overwinter shifts in the feeding ecology of juvenile Chinook salmon. ICES Journal of Marine Science 74: 226-233.

Houziaux, J.-S., Kerckhof, F., Degrendele, K., Roche, M, \& Norro, A., 2008. The Hinder Banks: Yet an important area for the Belgian marine biodiversity? Scientific support plan for a sustainable development policy (SPSD II): 248.

Hyslop, E. J., 1980. Stomach contents analysis-a review of methods and their application. Journal of Fish Biology 17: 411-429.

Jackson, A. L., R. Inger, A. C. Parnell \& S. Bearhop, 2011. Comparing isotopic niche widths among and within communities: SIBER-Stable Isotope Bayesian Ellipses in R. Journal of Animal Ecology 80: 595-602.

Jardas, I., M. Šantić \& A. Pallaoro, 2004. Diet composition and feeding intensity of horse mackerel, Trachurus trachurus (Osteichthyes: Carangidae) in the eastern Adriatic. Marine Biology 144: 1051-1056.

Jennings, S. \& S. M. Cogan, 2015. Nitrogen and carbon stable isotope variation in northeast Atlantic fishes and squids. Ecology 96: 2568.

Jensen, H., M. Kiljunen \& P. A. Amundsen, 2012. Dietary ontogeny and niche shift to piscivory in lacustrine brown trout Salmo trutta revealed by stomach content and stable isotope analyses. Journal of Fish Biology 80: 2448-2462.

Kadye, W. T. \& A. J. Booth, 2012. Integrating stomach content and stable isotope analyses to elucidate the feeding habits of non-native sharptooth catfish Clarias gariepinus. Biological Invasions 14: 779-795.

Kerckhof, F., B. Rumes \& S. Degraer, 2018. A closer look at the fish fauna of artificial hard substrata of offshore renewables in Belgian waters. In Degraer, S., R. Brabant, B. Rumes \& L. Vigin (eds), Environmental Impacts of Offshore Wind Farms in the Belgian Part of the North Sea: Assessing and Managing Effect Spheres of Influence. Royal Belgian Institute of Natural Sciences, OD Natural Environment, Marine Ecology and Management, Brussels: 79-89.

Kürten, B., I. Frutos, U. Struck, S. J. Painting, N. V. C. Polunin \& J. J. Middelburg, 2013. Trophodynamics and functional feeding groups of North Sea fauna: a combined stable isotope and fatty acid approach. Biogeochemistry 113: 189-212.

Lamontagne, S., B. M. Deegan, K. T. Aldridge, J. D. Brookes \& M. C. Geddes, 2016. Fish diets in a freshwater-deprived semiarid estuary (The Coorong, Australia) as inferred by stable isotope analysis. Estuarine, Coastal and Shelf Science Elsevier Ltd 178: 1-11.

Leitão, F., M. N. Santos \& C. C. Monteiro, 2007. Contribution of artificial reefs to the diet of the white sea bream (Diplodus sargus). ICES Journal of Marine Science 64: 473-478.

Leonhard, S. B., \& Pedersen, J., 2006. Benthic Communities at Horns Rev Before, During and After Construcytion of Horns Rev Offshore Wind Farm. Final report 2005. Udarbejdet afBio/consult as for ELSAM Engineering: 96.

Lin, H. J., W. Y. Kao \& Y. T. Wang, 2007. Analyses of stomach contents and stable isotopes reveal food sources of estuarine detritivorous fish in tropical/subtropical Taiwan. Estuarine, Coastal and Shelf Science 73: 527-537.

Lindberg, W. J., 1997. Can science resolve the attraction-production issue? Fisheries 22: 10-13.

López-Jamar, E., J. Iglesias \& J. Otero, 1984. Contribution of infauna and mussel-raft epifauna to demersal fish diets. Marine Ecology Progress Series 15: 13-18.

Mangi, S. C., 2013. The impact of offshore wind farms on marine ecosystems: a review taking an ecosystem services perspective. Proceedings of the IEEE 101: 999-1009.

Mavraki, N., I. De Mesel, S. Degraer, T. Moens \& J. Vanaverbeke, 2020a. Resource niches of co-occurring invertebrate species at an offshore wind turbine indicate a substantial degree of trophic plasticity. Frontiers in Marine Science 7: 379.

Mavraki, N., S. Degraer, T. Moens \& J. Vanaverbeke, 2020 b. Functional differences in trophic structure of offshore wind farm communities: a stable isotope study. Marine Environmental Research 157: 104868.

Melville, A. J. \& R. M. Connolly, 2003. Spatial analysis of stable isotope data to determine primary sources of nutrition for fish. Oecologia 136: 499-507.

Michaud, J. \& C. T. Taggart, 2007. Lipid and gross energy content of North Atlantic right whale food, Calanus finmarchicus, in the Bay of Fundy. Endangered Species Research 3: 77-94. 
Mittelbach, G. G. \& L. Persson, 1998. The ontogeny of piscivory and its ecological consequences. Canadian Journal of Fisheries and Aquatic Scniences 55: 1454-1465.

Morris, R. L., A. G. Porter, W. F. Figueira, R. A. Coleman, E. K. Fobert \& R. Ferrari, 2018. Fish-smart seawalls: a decision tool for adaptive management of marine infrastructure. Frontiers in Ecology and the Environment 16: 278-287.

Newsome, S. D., C. M. del Rio, S. Bearhop \& D. L. Phillips, 2007. A niche for isotopic ecology. Frontiers in Ecology and the Environment 5: 429-436.

Nilsen, M., T. Pedersen, E. M. Nilssen \& S. Fredriksen, 2008. Trophic studies in a high-latitude fjord ecosystem-a comparison of stable isotope analyses $\left(\delta^{13} \mathrm{C}\right.$ and $\left.\delta^{15} \mathrm{~N}\right)$ and trophic-level estimates from a mass-balance model. Canadian Journal of Fisheries and Aquatic Sciences 65: 2791-2806.

O’Brien-MacDonald, K., J. A. Brown \& C. C. Parrish, 2006. Growth, behaviour, and digestive enzyme activity in larval Atlantic cod (Gadus morhua) in relation to rotifer lipid. ICES Journal of Marine Science 63: 275-284.

Parkyn, S. M., K. J. Collier \& B. J. Hicks, 2001. New Zealand stream crayfish: functional omnivores but trophic predators? Freshwater Biology 46: 641-652.

Parnell, A. C., \& Inger, R., 2019. Stable isotope mixing models in $\mathrm{R}$ with SIMMR: a stable isotope mixing model. Version 0.4.1. https://cran.r-project.org/web/packages/simmr/.

Parnell, A. C., R. Inger, S. Bearhop \& A. L. Jackson, 2010. Source partitioning using stable isotopes: coping with too much variation. PLOS ONE 5: 1-5.

Parnell, A. C., D. L. Phillips, S. Bearhop, B. X. Semmens, E. J. Ward, J. W. Moore, A. L. Jackson, J. Grey, D. J. Kelly \& R. Inger, 2013. Bayesian stable isotope mixing models. Environmetrics 24: 387-399.

Peire, K., H. Nonneman \& E. Bosschem, 2009. Gravity based foundations for the Thornton Bank offshore wind farm. Terra et Aqua 115: 19-29.

Petersen, J. K. \& T. Malm, 2006. Offshore windmill farms: threats to or possibilities for the marine environment. AMBIO: A Journal of the Human Environment 35: 75-80.

Phillips, D. L. \& J. W. Gregg, 2003. Source partitioning using stable isotopes: coping with too many sources. Oecologia 136: 261-269.

Phillips, D. L., R. Inger, S. Bearhop, A. L. Jackson, J. W. Moore, A. C. Parnell, B. X. Semmens \& E. J. Ward, 2014. Best practices for use of stable isotope mixing models in foodweb studies. Canadian Journal of Zoology 92: 823-835.

Pinnegar, J. K. \& N. V. C. Polunin, 1999. Differential fractionation of $\delta^{13} \mathrm{C}$ and $\delta^{15} \mathrm{~N}$ among fish tissues: implications for the study of trophic interactions. Functional Ecology 13: 225-231.

Powers, S. P., J. H. Grabowski, C. H. Peterson \& W. J. Lindberg, 2003. Estimating enhancement of fish production by offshore artificial reefs: uncertainty exhibited by divergent scenarios. Marine Ecology Progress Series 264: 265-277.

R Development Core Team, 2018. R: A language and environment for statistical computing. R Foundation for Statistical Computing, Vienna, Austria.

Reeves, D. B., E. J. Chesney, R. T. Munnelly, D. M. Baltz \& K. Maiti, 2019. Trophic ecology of sheepshead and stone crabs at oil and gas platforms in the Northern Gulf of
Mexico's hypoxic zone. Transactions of the American Fisheries Society 148: 324-338.

Reubens, J., 2013. The ecology of benthopelagic fish at offshore wind farms: towards an integrated management approach.

Reubens, J. T., S. Degraer \& M. Vincx, 2011. Aggregation and feeding behaviour of pouting (Trisopterus luscus) at wind turbines in the Belgian part of the North Sea. Fisheries Research 108: 223-227.

Reubens, J. T., U. Braeckman, J. Vanaverbeke, C. Van Colen, S. Degraer \& M. Vincx, 2013a. Aggregation at windmill artificial reefs: CPUE of Atlantic cod (Gadus morhua) and pouting (Trisopterus luscus) at different habitats in the Belgian part of the North Sea. Fisheries Research 139: 28-34.

Reubens, J. T., F. Pasotti, S. Degraer \& M. Vincx, $2013 \mathrm{~b}$. Residency, site fidelity and habitat use of atlantic cod (Gadus morhua) at an offshore wind farm using acoustic telemetry. Marine Environmental Research 90: 128-135.

Reubens, J. T., S. Vandendriessche, A. N. Zenner, S. Degraer \& M. Vincx, 2013c. Offshore wind farms as productive sites or ecological traps for gadoid fishes? Impact on growth, condition index and diet composition. Marine Environmental Research 90: 66-74.

Reubens, J. T., M. De Rijcke, S. Degraer \& M. Vincx, 2014a. Diel variation in feeding and movement patterns of juvenile Atlantic cod at offshore wind farms. Journal of Sea Research 85: 214-221.

Reubens, J. T., S. Degraer \& M. Vincx, 2014b. The ecology of benthopelagic fishes at offshore wind farms: a synthesis of 4 years of research. Hydrobiologia 727: 121-136.

Rumolo, P., G. Basilone, E. Fanelli, M. Barra, M. Calabrò, S. Genovese, S. Gherardi, R. Ferreri, S. Mazzola \& A. Bonanno, 2017. Linking spatial distribution and feeding behavior of Atlantic horse mackerel (Trachurus trachurus) in the Strait of Sicily (Central Mediterranean Sea). Journal of Sea Research 121: 47-58.

Samples, K. C. \& J. T. Sproul, 1985. Fish aggregating devices and open-access commercial fisheries: a theoretical inquiry. Bulletin of Marine Science 37: 305-317.

Sargent, J., L. McEvoy, A. Estevez, G. Bell, M. Bell, J. Henderson \& D. Tocher, 1999. Lipid nutrition of marine fish during early development: current status and future directions. Aquaculture 179: 217-229.

Soma, K., S. W. K. van den Burg, T. Selnes \& C. M. van der Heide, 2019. Assessing social innovation across offshore sectors in the Dutch North Sea. Ocean and Coastal Management 167: 42-51.

St John, J., 1999. Ontogenetic changes in the diet of the coral reef grouper grouper Plectropomus leopardus (Serranidae): patterns in taxa, size and habitat of prey. Marine Ecology Progress Series 180: 233-246.

Strelcheck, A. J., J. H. Cowan \& A. Shah, 2005. Influence of reef location on artificial-reef fish assemblages in the northcentral Gulf of Mexico. Bulletin of Marine Science 77: 425-440.

Svane, I. \& J. K. Petersen, 2001. On the problems of epibioses, fouling and artificial reefs, a review. Marine Ecology 22: 169-188.

Urzúa, Á. \& K. Anger, 2013. Seasonal variations in larval biomass and biochemical composition of brown shrimp, 
Crangon crangon (Decapoda, Caridea), at hatching. Helgoland Marine Research 67: 267-277.

Van Ginderdeuren, K., S. Vandendriessche, Y. Prössler, H. Matola, M. Vincx \& K. Hostens, 2014. Selective feeding by pelagic fish in the Belgian part of the North Sea. ICES Journal of Marine Science 71: 808-820.

Veenstra, H. J., 1969. Gravels of the southern North Sea. Marine Geology 7: 449-464.

Wilhelmsson, D., T. Malm \& M. C. Ohman, 2006. The influence of offshore windpower on demersal fish. ICES Journal of Marine Science 63: 775-784.
Zintzen, V., 2007. Biodiversity of shipwrecks from the Southern Bight of the North Sea. PhD thesis, Université Catholique de Louvain, Leuven: 337.

Publisher's Note Springer Nature remains neutral with regard to jurisdictional claims in published maps and institutional affiliations. 